\title{
A Community-Based Study of Mucopolysaccharidosis Type VI in Brazil: The Influence of Founder Effect, Endogamy and Consanguinity
}

\author{
Fabiana Moura Costa-Motta ${ }^{a-c}$ Fernanda Bender ${ }^{a, b} \quad$ Angelina Acosta $^{d-g}$ \\ Kiyoko Abé-Sandes ${ }^{d, e, h, i}$ Taísa Machado ${ }^{e, i}$ Thaís Bomfim ${ }^{e, i}$ Tatiana Boa Sorte ${ }^{j, k}$ \\ Danniel da Silva ${ }^{e}$ Alan Bittles ${ }^{g, l}$ Roberto Giugliania, d, m Sandra Leistner-Segala, b \\ a Medical Genetics Service, Hospital de Clínicas de Porto Alegre, Porto Alegre, ${ }^{b}$ Postgraduate Program in Medicine: \\ Medical Sciences, UFRGS, Porto Alegre, ${ }^{C}$ Catholic University of Pelotas, Pelotas, ${ }^{d}$ National Institute on Population Medical \\ Genetics - INAGEMP, Brazil, 'e Advanced Laboratory of Public Health, Gonçalo Moniz Research Center, FIOCRUZ, Salvador, and \\ ${ }^{f}$ Bahia School of Medicine, UFBA, Salvador, Brazil; ${ }^{9}$ Centre for Comparative Genomics, Murdoch University, Perth, Australia; \\ ${ }^{\mathrm{h}}$ State University of Bahia, UNEB, Salvador, 'Laboratory of Immunology and Molecular Biology, ICS/UFBA, Salvador, \\ ${ }^{j}$ Bahia School of Medicine and Public Health, FBDC, Salvador, and ${ }^{k}$ Association of Parents and Friends of Exceptional from \\ Salvador, APAE, Salvador, Brazil; 'School of Medical Sciences, Edith Cowan University, Perth, Australia; ${ }^{\mathrm{m}}$ Department of \\ Genetics, UFRGS, Porto Alegre, Brazil
}

\section{Key Words}

Consanguinity · Founder effect · Genetic counselling ·

Mucopolysaccharidosis VI

\begin{abstract}
Mucopolysaccharidosis type VI (MPS VI - Maroteaux-Lamy syndrome) is a globally rare lysosomal storage disease caused by a deficiency of arylsulfatase B. However, in Monte Santo, a poor and isolated rural region in Northeast Brazil with large family sizes and high rates of community endogamy and parental consanguinity ( $a=0.00483$ ), 9 living and 4 now deceased individuals in 11 kindreds have been diagnosed with MPS VI, all with the same p.H178 L missense founder mutation. A further 33 deceased persons have been identified by family members as exhibiting the disease phenotype. Detailed pedigrees were constructed for the 13 genomically confirmed MPS VI patients, with blood samples collected from 236 unaffected family members to determine the prevalence of the p.H178 L mutation. A total of $98(20.8 \%)$ mutant
\end{abstract}

\section{KARGER}

E-Mail karger@karger.com

www.karger.com/hhe alleles and 374 (79.2\%) normal alleles were identified, with $41.5 \%$ of the individuals heterozygous for the p.H178 L mutation and $58.5 \%$ homozygous for the normal allele. A significant number of other family members with a 50 or $25 \%$ chance of being heterozygous for the p.H178 L mutation were unavailable for testing. The data indicate a compelling case for community-based neonatal screening in conjunction with further initiatives among MPS VI family members to promote genetic education and genetic counselling.

(c) 2014 S. Karger AG, Basel

\section{Introduction}

Mucopolysaccharidosis type VI (MPS VI; MaroteauxLamy syndrome; OMIM 253200) is a lysosomal storage disease caused by a deficiency of arylsulfatase B (ARSB, $\mathrm{N}$-acetylgalactosamine-4-sulfatase), which is required for the degradation of dermatan and chondroitin sulfates [1]. A deficiency of ARSB causes the accumulation of partial- 

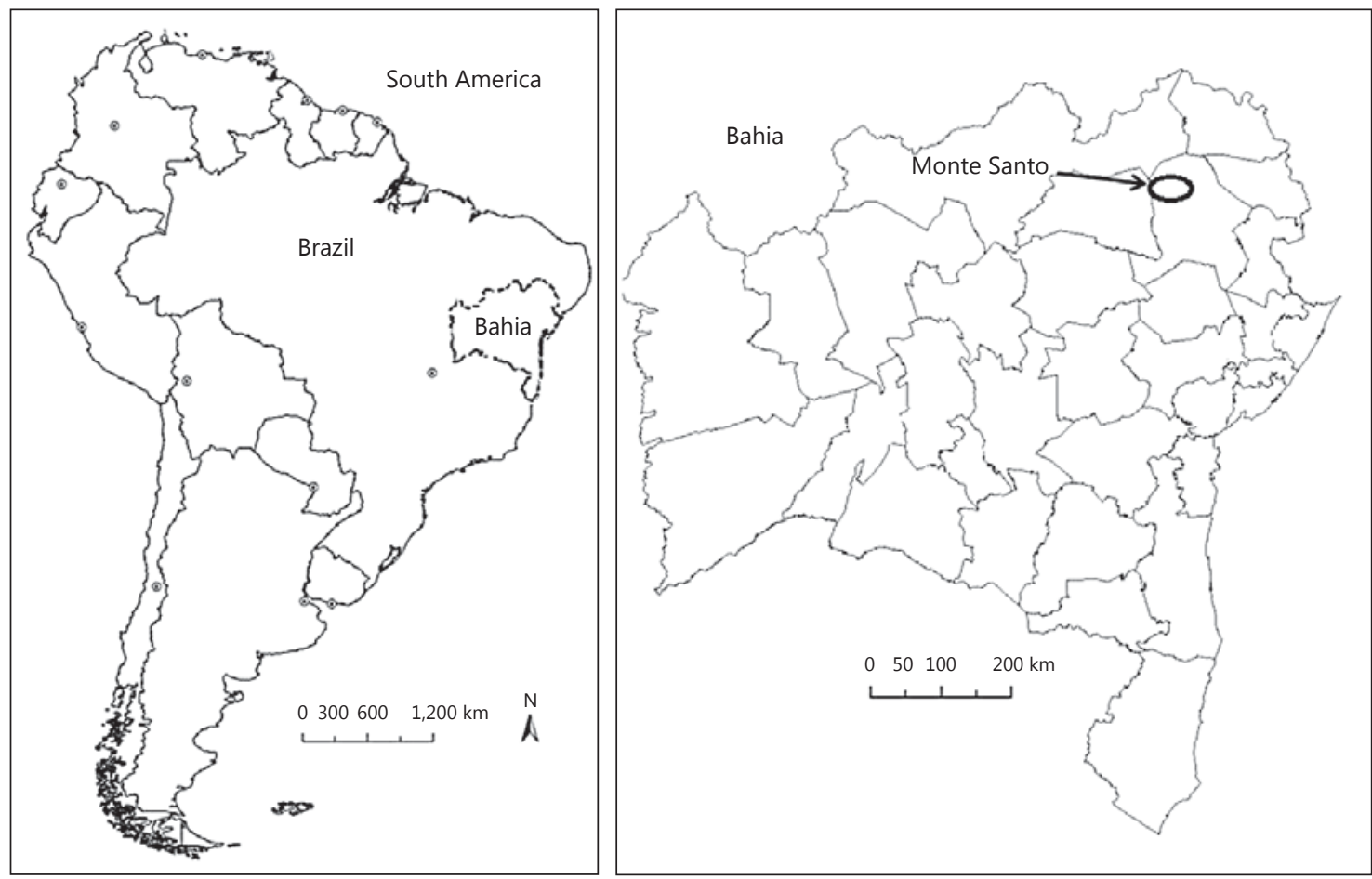

Fig. 1. Geographical location of Monte Santo (state of Bahia, Brazil).

ly degraded glycosaminoglycans in the lysosomes of a wide range of tissues, resulting in chronic progressive changes involving multiple organ systems and with death commonly occurring during the first two decades [2].

The disorder is, however, clinically heterogeneous and, in a minority of patients, the disease progression is slow with fewer systems implicated and mild or attenuated symptoms. The characteristic skeletal dysplasia includes short stature, dysostosis multiplex, and degenerative joint disease. Other clinical findings may include cardiac valve disease, reduced pulmonary function, hepatosplenomegaly, sinusitis, otitis media, hearing loss, sleep apnea, corneal clouding, carpal tunnel disease, and inguinal or umbilical hernia $[3,4]$. The isolation and characterization of human ARSB cDNA $[5,6]$ and partial elucidation of the gene structure [7] have allowed the identification of causative molecular defects. Human ARSB is $209 \mathrm{~kb}$ long (genome.ucsc.edu), comprising 8 exons ranging in size from 71 to $885 \mathrm{bp}$, and the nascent polypeptide has 533 amino acids [8]. Some 140 ARSB mutations have been described so far, and a number of polymorphisms have also been identified in the gene sequence $[9,10]$.

Hematopoietic stem cell transplantation has been employed for the treatment of MPS VI with variable success
[11]. An efficient and specific treatment based on enzyme replacement therapy (ERT) is, however, available [12, 13], and the successful adoption of ERT in patients with MPS VI has now been reported in many countries $[3,14]$. It has also been demonstrated that early initiation of ERT offers significant advantages in slowing or even preventing the development of significant pathological changes $[15,16]$.

The municipality of Monte Santo in Northeast Brazil is located approximately $350 \mathrm{~km}$ from Salvador, the capital of the state of Bahia and, according to the 2010 Census of Brazil [17], it had 52,338 inhabitants, with approximately $20 \%$ of the population resident in the town of Monte Santo itself and the remaining $80 \%$ dispersed across some 200 villages, a number of which are geographically remote (fig. 1). As in other states of Northeast Brazil, e.g. Rio Grande do Norte and Paraíba [18, 19], there is a strong tradition of community endogamy and consanguineous marriage, in part due to geographical and social isolation. To date, 13 cases of MPS VI, 9 living and 4 now deceased, have been confirmed by clinical examination and genomic analysis, and each of these patients was shown to be homozygous for the $A R S B$ p.H178L missense mutation. The results are strongly suggestive of 


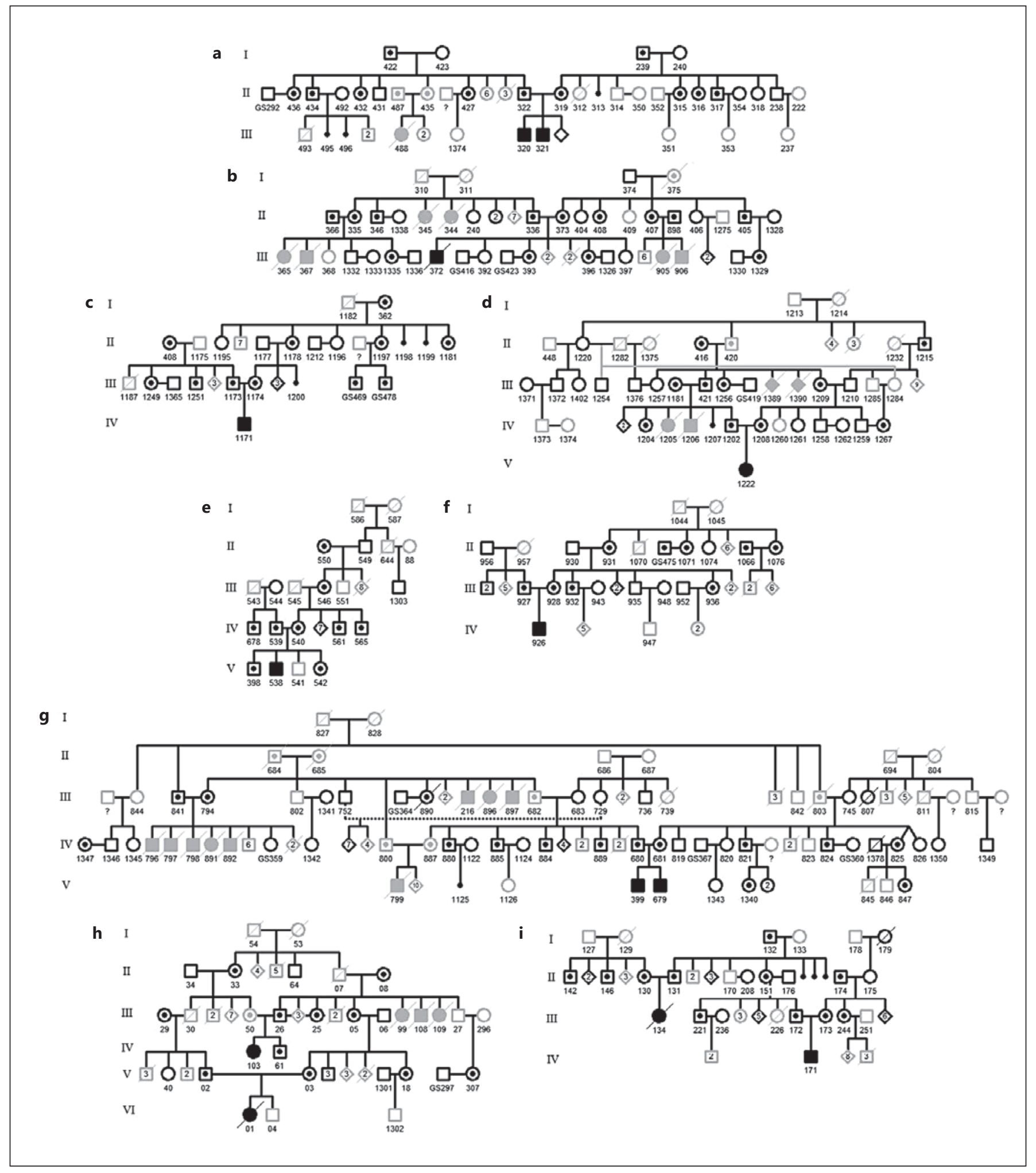

Fig. 2. Pedigrees of MPS VI kindreds: a-i kindreds 1-9. 
Table 1. Clinical profile of the MPS VI patients

\begin{tabular}{lllll}
\hline Patients & Gender & $\begin{array}{l}\text { Year of } \\
\text { birth/death }\end{array}$ & $\begin{array}{l}\text { Age at onset, } \\
\text { months }\end{array}$ & $\begin{array}{l}\text { Start of } \\
\text { ERT }\end{array}$ \\
\hline $1^{\mathrm{a}}$ & $\mathrm{M}$ & 1997 & 1 & 2008 \\
$2^{\mathrm{a}}$ & $\mathrm{M}$ & 2000 & 12 & 2008 \\
3 & $\mathrm{M}$ & 2004 & 5 & 2008 \\
$4^{\mathrm{b}}$ & $\mathrm{M}$ & 2001 & at birth & 2008 \\
$5^{\mathrm{b}}$ & $\mathrm{M}$ & 2008 & 12 & 2008 \\
6 & $\mathrm{M}$ & 2007 & 15 & 2010 \\
7 & $\mathrm{~F}$ & 2008 & 10 & 2010 \\
8 & $\mathrm{M}$ & 2005 & 2 & 2009 \\
9 & $\mathrm{~F}$ & 1989 & NI & \\
\hline 10 & $\mathrm{M}$ & $1987 / 2006$ & NI & \\
11 & $\mathrm{~F}$ & $1998 / 2008$ & NI & 2008 \\
12 & F & $2004 / 2011$ & at birth & 2008 \\
13 & M & $2000 / 2011$ & 24 & \\
\hline
\end{tabular}

Patients with identical superscripts are siblings. NI = No information.

a founder effect that has resulted in a high frequency of the p.H178L mutation in this mainly rural area [20], an opinion strongly supported by the detailed genealogical data collected as part of the present investigation (fig. 2).

Efficient and cost-effective screening of p.H178L homozygotes and heterozygotes in Monte Santo is possible since the mutation is readily detected by restriction fragment length polymorphism (RFLP) [20]. The principal aim of the present study was to determine the incidence of the ARSB p.H178L mutation in relatives of the 13 known MPS VI patients from Monte Santo and, on the basis of the results, to provide genetic counselling to affected families and genetic education programs to the wider community.

\section{Materials and Methods}

\section{Study Sample}

Since 2006 the research team has undertaken 8 trips to Monte Santo. As part of each visit, blood samples $(n=236)$ were collected from the relatives of individuals diagnosed with MPS VI to identify people heterozygous for the $A R S B$ p.H178L allele or at substantial risk of being carriers, as well as their partners and any progeny over 18 years of age. All participants gave written informed consent approved by the ethics committees of the institutions involved in the project. Based on the information provided by family members, a comprehensive genealogy was created and extensive pedigrees were constructed.
Mutation Detection

Mutation detection followed the protocol described by CostaMotta et al. [20]. Genomic DNA was obtained using the salting-out precipitation technique [21], with amplification of exon $3^{\prime}$ of the $A R S B$ gene by polymerase chain reaction (PCR). PCR amplification was performed in final volumes of $25 \mu \mathrm{l}$ with $2 \mathrm{mM} \mathrm{MgCl}_{2}$, $1 \mathrm{mM}$ of each dNTP, $10 \mathrm{pmol}$ of each primer, $2.0 \mu \mathrm{l}$ of DMSO $100 \%$, $1 \times$ PCR buffer, $1 \mathrm{U}$ of Taq DNA polymerase (Super-Therm and Invitrogen), and 100-200 ng of genomic DNA. The reactions were subjected to $5 \mathrm{~min}$ of initial denaturation at $94^{\circ} \mathrm{C}$, and 30 cycles of denaturation at $94^{\circ} \mathrm{C}$ for $40 \mathrm{~s}$, annealing at $47^{\circ} \mathrm{C}$ for $40 \mathrm{~s}$, and elongation at $72^{\circ} \mathrm{C}$ for $40 \mathrm{~s}$, with a final extension step at $72^{\circ} \mathrm{C}$ for 10 min. The primers used to amplify the exon were the same as described by Petry et al. [22], and the PCR products were analyzed in $1.5 \%$ agarose gels containing ethidium bromide.

After the amplification by PCR, the products were subjected to RFLP analysis with the Hsp92II enzyme. Restriction enzyme incubations were set for $30-\mu \mathrm{l}$ reactions with $3 \mu \mathrm{l}$ of $10 \times$ buffer, $0.5 \mu \mathrm{l}$ of enzyme (5 U), and 10-20 $\mu$ l of PCR product (depending on the intensity of the band after amplification). Milli-Q water was used to make up the rest of the volume for the reaction. Incubations were carried out overnight at $37^{\circ} \mathrm{C}$, and the resultant fragments were visualized in a $3 \%$ agarose gel containing ethidium bromide.

\section{Pedigrees}

Detailed pedigrees, which included all individuals sampled and their close family members, were constructed using the program GenoPro ${ }^{\circledR} 2011$ (version 2.5.3.2). CFC software (Contribution, Inbreeding (F), Coancestry - release 1.0, April 2006) was used to calculate the mean coefficients of inbreeding $(\alpha)$. To facilitate data interpretation and taking into account the close relationship of some index cases, the 11 kindreds with affected members were grouped into 9 pedigrees (fig. 2). In all pedigrees, individuals represented by black symbols were analyzed by RFLP. Those represented by grey symbols were unavailable for analysis, either because they were under 18 years of age or they were no longer resident in the state of Bahia. MPS VI patients are represented by completely filled symbols, while individuals heterozygous for the $A R S B$ p.H178L allele are shown with a central dot within the symbol.

\section{Genetic Counselling}

Pre- and post-test genetic counselling was conducted by trained staff, i.e. physicians and psychologists, who provided advice and support to individuals, couples, and families. Information was provided on the implications of the test for the p.H178L allele, the possible genotypes that may be identified and their clinical significance, and the chances of having an affected child when both parents are heterozygous for the disease mutation.

\section{Results}

Of the 9 living patients with MPS VI in Monte Santo, 7 were males and 2 were females. They were between 4 and 23 years of age, and all of them were homozygous for the p.H178L missense mutation. The 4 deceased Monte Santo patients, 2 males and 2 females, were between 7 and 
Table 2. Data on individuals heterozygous for the p.H178L mutation, subdivided into 9 pedigrees representing 11 nuclear families

\begin{tabular}{llllll}
\hline $\begin{array}{l}\text { Nuclear } \\
\text { family }\end{array}$ & Pedigree & $\begin{array}{l}\text { Individuals, } \\
\mathrm{n}\end{array}$ & $\begin{array}{l}\text { MPS VI } \\
\text { patients, } \\
\mathrm{n}\end{array}$ & $\begin{array}{l}\text { Subjects with } \\
\text { molecular } \\
\text { analysis, n (\%) }\end{array}$ & $\begin{array}{l}\text { Subjects } \\
\text { heterozygous for } \\
\text { p.H178L, n (\%) }\end{array}$ \\
\hline 1 & $\mathrm{a}$ & 50 & $2^{\mathrm{a}}$ & $22(44)$ & $11(22)$ \\
2 & $\mathrm{~b}$ & 62 & 1 & $33(53)$ & $13(21)$ \\
3 & $\mathrm{c}$ & 37 & 1 & $20(54)$ & $10(27)$ \\
4 & $\mathrm{~d}$ & 59 & 1 & $26(44)$ & $9(16)$ \\
5 & $\mathrm{e}$ & 36 & 1 & $20(56)$ & $9(25)$ \\
6 & $\mathrm{f}$ & 54 & 1 & $21(38)$ & $9(19)$ \\
7 & $\mathrm{~g}$ & 138 & $2^{\mathrm{a}}$ & $53(38)$ & $15(12)$ \\
8 & $\mathrm{~h}$ & 67 & $2^{\mathrm{b}}$ & $22(33)$ & $11(16)$ \\
9 & $\mathrm{i}$ & 65 & $2^{\mathrm{b}}$ & $34(52)$ & $11(17)$ \\
\hline
\end{tabular}

${ }^{a}$ Patients are siblings. ${ }^{b}$ Patients are close relatives, i.e. first cousins $(\mathrm{F}=0.0625)$ or second cousins $(\mathrm{F}=0.0156)$.

19 years of age at their death and, prior to death, they had also been shown to be homozygous for the p.H178L mutation (table 1). By comparison, c.1533del23 has been reported to be the most common MPS VI mutation elsewhere in Brazil $[22,23]$. In addition to the 13 genomically confirmed cases, family members identified another 33 deceased persons with the characteristic MPS VI phenotype who had died at between 1 and 24 years of age (table 2; fig. 2).

On the basis of the genealogical information provided by families, 1,413 individuals in Monte Santo were identified as being potential heterozygotes for the $A R S B$ p.H178L mutation. The mean coefficient of inbreeding determined from the overall genealogy was $\alpha=0.00483$. Of all alleles analyzed by RFLP $(\mathrm{n}=472), 98(20.8 \%)$ were p.H178L mutant alleles and 374 (79.2\%) were normal alleles. Thus, $41.5 \%$ of the study group were heterozygous for p.H178L and 58.5\% were homozygous for the normal allele.

\section{Kindred 1 (fig. 2a)}

Besides patients Nos. 320 and 321, relatives reported the presence of another individual with MPS VI (fig. 2a: No. 488), but this first cousin had died prior to the commencement of the study and blood could not be collected from her parents who now live in the metropolis of São Paulo, which is situated some 2,000 km from Monte Santo. The couple in question has 2 other adult children, who also live in São Paulo, and if parental heterozygosity was confirmed, they would have a $50 \%$ risk of being carriers of the p.H178L allele. A number of individuals were iden-

A Community-Based Study of MPS VI in Brazil tified in this kindred with a $25 \%$ chance of being heterozygous for the p.H178L allele, but they could not be sampled because they were under 18 years at the time of investigation. Several individuals who were not analyzed but may have an important role in the maintenance of the mutant allele in the region were omitted from the present pedigree due to sizing constraints, e.g. the 12 additional siblings of individual No. 422 and the 8 siblings of individual No. 239 (fig. 2a), both of whom are heterozygous for the p.H178L allele.

\section{Kindred 2 (fig. 2b)}

The complex inter-related nature of many of the pedigrees is illustrated by individual No. 240 who appears in the pedigree of kindred 1 as a grandmother of brothers Nos. 320 and 321 (fig. 2a) diagnosed with MPS VI and in the pedigree of kindred 2 as a paternal aunt of MPS VI patient No. 372 (fig. 2b). Molecular analysis was not possible for 6 individuals identified by relatives as having MPS VI (fig. 2b: Nos. 344, 345, 365, 367, 905, and 906) as they were already deceased. However, DNA was obtained from 2 couples (fig. 2b: Nos. 335 and 366, 407 and 898), who were the parents of some of these individuals (fig. 2b: Nos. 365, 367 and 905, 906), with parental heterozygosity for MPS VI confirmed. As in kindred 1, a number of persons in kindred 2 with a $50 \%$ chance of being heterozygous for the p.H178L allele could not be analyzed because they live in São Paulo. Due to sizing constraints, some individuals who have not been analyzed were omitted from figure $2 \mathrm{~b}$, e.g. the 7 additional siblings of individual No. 375 who is probably heterozygous for the p.H178L allele and the 3 siblings of individual No. 898 who was confirmed as heterozygous for p.H178L.

\section{Kindred 3 (fig. 2c)}

Individual No. 408 appears in the pedigree of kindred 2 as a maternal aunt of MPS VI patient No. 372 (fig. 2b) and in the pedigree of kindred 3 as a grandmother of MPS VI patient No. 1171 (fig. 2c). Heterozygous individual No. 362 (fig. 2c) is a sister of individual No. 311 in kindred 2 , and they have 2 brothers not included in the pedigree(s) who have a $50 \%$ risk of being heterozygous for p.H178L. As before, some individuals in this kindred were unavailable for analysis because they now live in São Paulo.

\section{Kindred 4 (fig. 2d)}

Individual No. 1181 is portrayed in kindred 4 as a grandmother of MPS VI patient No. 1222 (fig. 2d) and in kindred 3 as a sister to the grandmother of MPS VI patient No. 1171 (fig. 2c). Similarly, individual No. 1374 in 
kindred 4 also appears in the pedigree of kindred 1 as a first cousin of MPS VI patient No. 320 (fig. 2a). Four additional individuals (fig. 2d) - Nos. 1205, 1206, 1389, and 1390 - were reported by family members to have had MPS VI but they had died prior to the present investigation. DNA was collected from 3 relatives of these deceased individuals (fig. 2d: Nos. 416, 421, and 1181), and heterozygosity for the p.H178L allele was confirmed. Of the 11 children of individual No. 1215, who is heterozygous for p.H178L, 10 were absent at the time of sample collection. One of these persons, No. 1210 who is normal for the p.H178L allele is the maternal grandfather of MPS VI patient No. 1222 and another son, No. 1285, has a heterozygous daughter, No. 1267.

\section{Kindred 5 (fig. 2e)}

One boy in this kindred, the brother of MPS VI patient No. 538 , has a $50 \%$ chance of being heterozygous for the p.H178L allele (fig. 2e: No. 541), but he could not be analyzed as he was under 18 years of age at the time of sample collection. A number of other persons were omitted from the pedigree either due to sizing constraints or because they had not been analyzed at the time of pedigree construction. They may, however, have an important role in the maintenance of the mutant allele, e.g. the additional 9 siblings of individual No. 550 (fig. 2e), who is heterozygous for the p.H178L allele.

\section{Kindred 6 (fig. 2f)}

This kindred has many individuals with a $50 \%$ chance of being heterozygous but who could not be analyzed, either because they are resident in other regions of Brazil, or they were not present at the time of blood collection. Likewise, it was not possible to collect blood from the 6 living children of heterozygous couple Nos. 1066 and 1076 , each of whom has a $50 \%$ chance of being heterozygous for the mutant allele. The deceased grandmother, No. 957, of MPS VI patient No. 926 also has another 7 siblings not indicated in the pedigree but who may be heterozygous for the p.H178L allele.

\section{Kindred 7 (fig. 2g)}

Confirmatory genomic diagnosis of homozygosity for the mutant p.H178L allele was available for 2 members of this kindred (fig. 2g: Nos. 399 and 679). Parental heterozygosity for the p.H178L allele was confirmed by genomic analysis in one couple (fig. 2g: Nos. 794 and 841). Five of their 14 children were deceased but were reported by relatives as having exhibited the characteristic phenotype of MPS VI. Relatives also reported 4 other deceased per- sons in this kindred as having the MPS VI phenotype (fig. 2g: Nos. 216, 799, 896, and 897).

\section{Kindred 8 (fig. 2h)}

Many of the relatives in this kindred could not be analyzed because they live in São Paulo. In addition, the brother, a first cousin, and a paternal uncle of MPS VI patient No. 01 (fig. 2h: Nos. 04, 1302, and 41, respectively), who each have a $50 \%$ chance of being heterozygous for the p.H178L mutation, could not be analyzed because at the time of sample collection they were under 18 years of age. Deceased subjects Nos. 99, 108, and 109, whose mother and 3 of whose siblings were confirmed heterozygotes for p.H178L, were reported by relatives to have shown the typical MPS VI phenotype. Individuals not analyzed who were omitted from the pedigree due to sizing constraints include the 6 siblings of individual No. 29 and the 8 siblings of individual No. 08 (fig. 2h), both of whom are heterozygous for the p.H178L allele. Each of these 14 individuals not represented in the pedigree thus have a $50 \%$ chance of being heterozygous for the p.H178L allele.

\section{Kindred 9 (fig. 2i)}

Two persons in this kindred were genomically confirmed as MPS VI (fig. 2i: Nos. 134 (deceased) and 171). No information was available on the ancestry of individual No. 132 to identify siblings who may be heterozygous for the p.H178L allele. Only 1 of the 8 living progeny of couple Nos. 244 and 251 was over 18 years of age, and she was unavailable at the time of sample collection. Both sons of couple Nos. 221 and 236 were also under 18 years of age, and so they were unavailable for molecular analysis.

\section{Discussion}

According to international studies, the incidence of MPS VI ranges from 1 in 43,261 births in Turkish migrants in Germany to 1 in 1,505,160 births in Sweden [3]. No incidence data for MPS VI in Brazil have been published, but information from the MPS Brazil Network appears to indicate that MPS VI is less rare than in other countries [Giugliani, pers. commun.]. It has also been reported that in Brazil [24] and in Portugal [25], from which many people migrated to Brazil, the frequency of MPS VI is high in comparison to other mucopolysaccharidoses. As indicated in figure 1, the rural municipality of Monte Santo alone exhibits more than 1 case per 5,000 live births, and this figure almost certainly is an underestimate given the additional 33 persons putatively identified by family 
members as having the characteristic MPS VI phenotype, but who had died before the start of the present study.

On each working visit to Monte Santo to deliver the results of genomic analyses, additional individuals with a $50 \%$ chance of being heterozygous were added to the genealogy and, where possible, blood samples were collected from these people for molecular analysis. Pedigree analysis (fig. 2) indicates the presence of many individuals with a 50 and $25 \%$ chance of being heterozygous for p.H178L, a significant number of whom could not be sampled either because they were under 18 years of age or they had relocated to distant regions of Brazil. The parents of the underage individuals were counselled and advised that when their children reached 18 years of age they could request molecular analysis from the research group. Genomic analysis is also freely available to individuals and families who are potential carriers of MPS VI but are no longer resident in Monte Santo.

From a wider perspective, the present study highlights the importance of comprehensive genealogical information in disentangling the complex genetic structures of small remote communities, where founder effect in combination with large family sizes, endogamy, and a high prevalence of consanguineous marriage in successive generations results in the expression of otherwise rare recessive disorders, such as MPS VI [4]. The highly complex intra- and interfamily relationships in Monte Santo are illustrated by individual No. 240 who is included in kindreds 1 and 2 (fig. 2a, b), individual No. 1374 in kindreds 1 and 4 (fig. 2a, d), individual No. 408 in kindreds 2 and 3 (fig. 2b, c), and individual No. 1181 in kindreds 3 and 4 (fig. 2c, d).
When MPS VI testing and diagnosis first became available, patients had to travel weekly to Salvador, the capital of Bahia, some $350 \mathrm{~km}$ from Monte Santo, to receive infusions of ERT. However, in April 2011, an ERT center was inaugurated at the municipal hospital of Monte Santo, where local doctors and nurses have been trained to provide treatment, often accompanied by the medical geneticist and psychologist responsible for genetic counselling. The implementation of the ERT center in Monte Santo and the high prevalence of heterozygotes (42\%) in the kindreds in which MPS VI has been shown to segregate have served to reinforce the importance of early identification of community members who are homozygous or heterozygous for the p.H178L mutation. A neonatal screening program, supported by genetic counselling and genetic education initiatives [26], has now also been established, so that premarital counselling and early disease diagnosis and treatment can be organized for affected individuals and their families, with the aim of reducing the overall burden of disease in this geographically remote low-income community.

\section{Acknowledgments}

This study was supported by institutional (FIPE-HCPA) and Brazilian Institute for Population Medical Genetics (INAGEMP grant: CNPq 573993/2008-4) funding. F.M.C.-M. was supported by a CAPES scholarship, and Drs. A.A., S.L.-S., and R.G. were in receipt of research grants from CNPq. During 2012/2013, Dr. A.A. was a Senior Visiting Researcher at the Centre for Comparative Genomics, Murdoch University, Perth, Australia.

\section{References}

1 Neufeld E, Muenzer J: The mucopolysaccharidoses; in Scriver C, Beaudet A, Valle D, Sly W (eds): The Metabolic and Molecular Bases of Inherited Disease. New York, McGraw-Hill, 2001, pp 3421-3452.

$\checkmark 2$ Harmatz P, Whitley CB, Waber L, Pais R, Steiner R, Plecko B, Kaplan P, Simon J, Butensky E, Hopwood JJ: Enzyme replacement therapy in mucopolysaccharidosis VI (Maroteaux-Lamy syndrome). J Pediatr 2004;144: 574-580.

-3 Valayannopoulos V, Nicely H, Harmatz P, Turbeville S: Mucopolysaccharidosis VI. Orpha J Rare Dis 2010;5:5.

4 Four Legacies: Populational Medical Genetics (in Portuguese: Quatro Heranças: Genética Médica Populacional), 2012. VERTE filmes. http://vimeo.com/53109501.

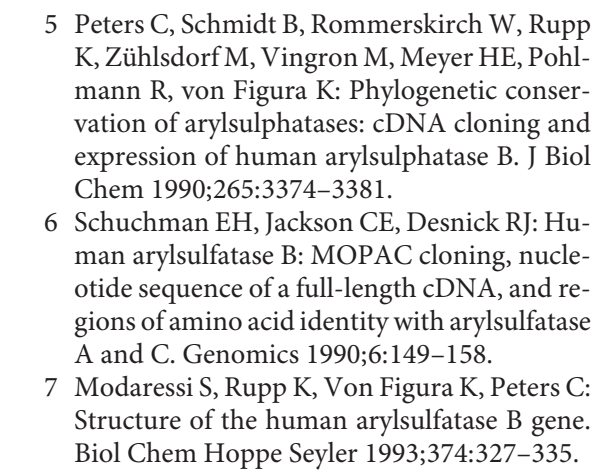

Peters C, Schmidt B, Rommerskirch W, Rupp K, Zühlsdorf M, Vingron M, Meyer HE, Pohlmann R, von Figura K: Phylogenetic conservation of arylsulphatases: cDNA cloning and expression of human arylsulphatase B. J Biol Chem 1990;265:3374-3381. o ide sequence of a full-length cDNA, and regions of amino acid identity with arylsulfatase $A$ and C. Genomics 1990;6:149-158. Biol Chem Hoppe Seyler 1993;374:327-335.

\footnotetext{
8 Kobayashi T, Honke K, Jin T, Gasa S, Miyazaki T, Makita A: Components and proteolytic processing sites of arylsulfatase B from human placenta. Biochim Biophys Acta 1992; 1159:243-247.

-9 Karageorgos L, Brooks DA, Pollard A, Melville EL, Hein LK, Clements PR, Ketteridge D, Swiedler SJ, Beck M, Giugliani R, Harmatz P, Wraith JE, Guffon N, Leão Teles E, Sá Miranda MC, Hopwood JJ: Mutational analysis of 105 mucopolysaccharidosis type VI patients. Hum Mutat 2007;28:897-903.

10 HGMD - The Human Gene Mutation Database: http://www.uwcm.ac.uk/uwcm/mg/ search/ (accessed October 1, 2012).
} 
11 Turbeville S, Nicely H, Rizzo, Pedersen TL, Orchard PJ, Horwitz ME, Horwitz EM, Veys $\mathrm{P}$, Bonfim C, Al-Seraihy A: Clinical outcomes following hematopoitic stem cell transplantation for the treatment of mucopolysaccharidosis VI. Mol Genet Metab 2011;102:111115.

12 Giugliani R, Harmatz P, Wraith JE: Management guidelines for mucopolysaccharidosis VI. Pediatrics 2007;120:405-418.

13 Harmatz P, Giugliani R, Schwartz IV, Guffon N, Teles EL, Miranda MC, Wraith JE, Beck M, Arash L, Scarpa M, Ketteridge D, Hopwood JJ, Plecko B, Steiner R, Whitley CB, Kaplan P, Yu ZF, Swiedler SJ, Decker C; MPS VI Study Group: Long-term follow-up of endurance and safety outcomes during enzyme replacement therapy for mucopolysaccharidosis VI: final results of three clinical studies of recombinant $\mathrm{N}$-acetylgalactosamine 4-sulfatase. Mol Genet Metab 2008;94:469-475.

14 Giugliani R, Carvalho CG, Herber S, de Camargo Pinto LL: Recent advances in treatment approaches of mucopolysaccharidosis VI. Curr Pharm Biotechnol 2011;12:956-962.

15 McGill JJ, Inwood AC, Coman DJ, Lipke ML, de Lore D, Swiedler SJ, Hopwood JJ: Enzyme replacement therapy for mucopolysaccharidosis VI from 8 weeks of age - a sibling control study. Clin Genet 2010;77:492-498.
16 Furujo M, Kubo T, Kosuga M, Okuyama T: Enzyme replacement therapy attenuates disease progression in two Japanese siblings with mucopolysaccharidosis type VI. Mol Genet Metab 2011;104:597-602.

17 IBGE - Instituto Brasileiro de Geografia e Estatística: www.ibge.gov.br (accessed October 21, 2012).

18 Santos S, Kok F, Weller M, Lopes de Paiva FR, Otto PA: Inbreeding levels in Northeast Brazil: strategies for the prospecting of new genetic disorders. Genet Mol Biol 2010;33:220 223.

19 Weller M, Tanieri M, Pereira JC, Almeida Edos S, Kok F, Santos S: Consanguineous unions and the burden of disability: a population-based study in communities of Northeastern Brazil. Am J Hum Biol 2012;24:835840.

20 Costa-Motta FMM, Acosta AX, Abé-Sandes K, Bender F, Schwarts IV, Giugliani R, Leistner-Segal S: Genetic studies in a cluster of mucopolysaccharidosis type VI patients in Northeast Brazil. Mol Genet Metab 2011;104: 603-607.
21 Miller S, Dykes D, Polesky H: A simple salting out procedure for extracting DNA from human nucleated cells. Nucleic Acids Res 1988; 16:1215.

22 Petry MFG, Nonemacher K, Sebben JC, Schwartz IV, Azevedo AC, Burin MG, de Rezende AR, Kim CA, Giugliani R, LeistnerSegal S: Mucopolysaccharidosis type VI: identification of novel mutations on the arylsulphatase B gene in South American patients. J Inher Metab Dis 2005;28:1027-1034.

23 Petry MF, Dieter T, Burin M, Giugliani R, Leistner S: Identification of a novel mutation in the ARSB gene that is frequent among Brazilian MPSVI patients. Genet Test 2003;7: 347-349.

24 Coelho JC, Wajner M, Burin MG, Vargas CR, Giugliani R: Selective screening of 10,000 high-risk Brazilian patients for the detection of inborn errors of metabolism. Eur J Pediatr 1997; 156:650-654.

25 Pinto R, Caseiro C, Lemos M, Lopes L, Fontes A, Ribeiro H, Pinto E, Silva E, Rocha S, Marcão A, Ribeiro I, Lacerda L, Ribeiro G, Amaral O, Sá Miranda MC: Prevalence of lysosomal storage diseases in Portugal. Eur J Hum Genet 2004;12:87-92.

-26 Acosta AX, Abé-Sandes K, Giugliani R, Bittles $\mathrm{AH}$ : Delivering genetic education and genetic counselling for rare diseases in rural Brazil. J Genet Counsel 2013;22:830-834. 